\title{
Evaluación de técnicas de control de marchitez bacteriana en tomate (Lycopersicon esculentum) de crecimiento determinado
}

\section{Luis Ernesto Trujillo Rodríguez}

Investigador

Programa de Hortalizas, Centro Nacional de Tecnología Agropecuaria y Forestal,

CENTA, El Salvador. Email: trujilloluisernesto@hotmail.com

Recepción: 2013-12-20

Aceptación: 2014-01-21

\section{RESUMEN}

Se evaluó la técnica de injerto en tomate para el control de marchitez bacteriana. El experimento se dividió en tres pruebas: 1) Confirmación de suelo contaminado con plantas de prueba; 2) Evaluación del injerto para controlar marchitez bacteriana y 3) Evaluación del uso de mulch. De acuerdo con los resultados, la técnica de injertar puede controlar la marchitez bacteriana en tomate determinado y la utilización de mulch no es esencial para controlar tal circunstancia en combinación con la técnica del injerto.

Palabras clave: Técnica de injerto, tomate, marchitez bacteriana, crecimiento determinado, mulch

\begin{abstract}
Graft technique was evaluated in tomato for controlling bacterial wilt. The experiment was divided into three tests: 1) Confirmation of poison soil with test plants; 2) Graft evaluation for controlling bacterial wilt, and 3) Evaluation of the use of mulch. According to the results, the graft technique can control bacterial wilt in tomato determined and the use of mulch is not essential for controlling bacterial wilt with the combination of graft technique.
\end{abstract}

Key words: Graft technique, tomato, bacterial wilt, determined growth, mulch 


\section{Introducción}

El tomate (Lycopersicon esculentum) es una de las hortalizas más importantes en El Salvador, debido a su utilización en la cocina tradicional. Las características sub-tropicales del clima del país hacen que la producción de esta especie sea favorable. La siembra de tomate en nuestro país se realiza en 813.4 hectáreas, lo que brinda una producción aproximada de 19202.5 toneladas de tomates. Es decir, 23 t/ ha. (Censo Agrícola 2007-2008). No obstante, la demanda anual de esta hortaliza es mayor, pues se consumen $83813 \mathrm{t}$ al año.

Al no suplirse esta demanda, el país importa grandes cantidades de tomate de otros países, especialmente de Guatemala y Honduras. El principal motivo por el cual existe una pobre producción de tomate en El Salvador es la dificultad del control adecuado de plaga y enfermedades. En el municipio de Tacuba, departamento de Ahuachapán, el ataque de marchitez bacterial y la inexistencia de un buen método de control implementado por los productores afectan grandemente la producción de tomate.

De acuerdo a muchos reportes técnicos de origen japonés -y a la experiencia personal del investigador- el uso del injerto en tomate de crecimiento determinado es efectivo para el control de marchitez bacterial.

Experimentos previos realizados en JICA
Tsukuba, Japón, explican la compatibilidad entre el patrón y el injerto; entre los patrones, la calidad de fruto y la productividad. Sin embargo, no existen reportes respecto al uso de la técnica de injerto en tomate.

El tomate de crecimiento determinado es la variedad más usada por los pequeños productores en El Salvador, ya que el mercado nacional demanda ese tipo de hortaliza. Esta clase de cultivo tiene la característica de producir gran cantidad de laterales, a diferencia del tomate indeterminado; además, esta variedad tiene más posibilidades de entrar en contacto con el suelo. Debido a esto, cabe la posibilidad de que el tomate determinado se contamine con marchitez bacteriana.

\section{Materiales y métodos}

\subsection{Etapas del experimento}

Esta faceta consistió en tres pruebas:

- Prueba a: Confirmación de existencia de marchitez bacteriana en el suelo a través de plantas de prueba

- Prueba b: Evaluación del injerto en tomate determinado para controlar marchitez bacteriana en un campo contaminado

- Prueba c: Evaluación del uso de mulch para conocer su efectividad en el control de marchitez bacteriana en condiciones 
donde los laterales del tomate tocan el suelo

\section{Prueba a. Confirmación de existencia de marchitez bacteriana en el suelo a través de plantas de prueba}

El ensayo se condujo en el invernadero de fitopatología en el Centro Internacional de Entrenamiento en Tsukuba, Japón, durante el periodo comprendido entre junio y julio de 2011.

\section{Materiales}

- Plantas de prueba: Cuatro variedades de tomate (Figura1)

- Suelo de prueba: El suelo fue tomado de un campo con antecedentes de problemas de marchitez bacteriana.

Figura 1. Variedades de tomate utilizadas

\begin{tabular}{|l|c|c|}
\hline \multicolumn{1}{|c|}{ Tipo } & Variedad & Información de compañía de semillas \\
\hline 1. Determinado & Walter & - \\
2. Indeterminado & Son road & Tolerante a marchitez bacteriana \\
3. Indeterminado & Shunrei & Tolerante a marchitez bacteriana \\
4. Indeterminado & Momotaro fight & Tolerante a marchitez bacteriana \\
\hline
\end{tabular}

Fuente: Elaboración propia

\section{Método de siembra}

Cada una de las cuatro variedades fue trasplantada hacia un recipiente con capacidad para almacenar un 1 galón. El depósito se llenó con tierra contaminada por la bacteria. Estos depósitos fueron puestos en el invernadero de fitopatología para observar la aparición de marchitez. La humedad del suelo se manejó cuidadosamente.

\section{Método de evaluación}

A los 32 días de haberse efectuado el trasplante, el tallo de las plantas que presentaron síntomas de marchitez se cortaron a una altura de $5 \mathrm{~cm}$ y $10 \mathrm{~cm}$ de distancia de la superficie del suelo para hacer la prueba de exudado bacteriano en agua, y así confirmar la presencia del fenómeno de estudio. De acuerdo a las fuentes consultadas, la prueba de laboratorio para detectar la presencia del patógeno no era necesaria. 
Prueba b. Evaluación del injerto en tomate determinado para controlar marchitez bacteriana en un campo contaminado

Esta prueba se realizó a campo abierto, específicamente en Arakawaoki, ciudad de Tsuchiura, Japón, durante los meses de junio a septiembre de 2011. La evaluación se llevó a cabo a los 42, 56 y 60 días después de la siembra. Además, este campo tiene antecedentes de problemas de marchitez bacteriana.

\section{Materiales}

- Injerto: Walter, variedad de tomate de crecimiento determinado susceptible a marchitez bacteriana

- Patrón: BF- OKITSU, variedad resistente a marchitez bacteriana ( Shrestha S., 2010)

\section{Tratamientos y repeticiones}

Tanto las plantas injertadas como las no injertadas fueron sembradas en el suelo contaminado. Se repartieron cinco plantas por bloque con dos repeticiones.

\section{Método de injerto}

El patrón se llevó a cabo el 7 de abril y el injerto se realizó el día 10 del mismo mes. Las plantas se injertaron el 2 de mayo, utilizando el método de corte mediante tubos. Después de ocho días de aclimatización dentro de un túnel plástico en el invernadero, las plantas tratadas fueron trasplantadas a recipientes de plástico de $12 \mathrm{~cm}$ de diámetro y llenadas con suelo esterilizado.

\section{Siembra y manejo del cultivo}

El transplante en suelo contaminado se hizo el 9 de julio del 2011, cuando las plantas injertadas y no injertadas tenían desarrollado el primer racimo floral. El espacio entre planta fue de $60 \mathrm{~cm}$ y entre calle, de $120 \mathrm{~cm}$. Se colocaron cinco plantas por bloque.

El fertilizante químico sulfato de amonio, súper fosfato y cloruro de potasio se utilizó para el experimento, aplicándolo una semana antes del trasplante e incorporándolo al suelo. El soporte de las plantas de tomate se hizo con tutores de plástico, colocados a lo largo de los bloques a una distancia de $2 \mathrm{~m}$ entre ellos para luego colocar una pita ${ }^{1}$, como se hace tradicionalmente en el país. También se realizaron otras prácticas culturales de forma estándar para todos los bloques.

\section{Método de evaluación}

El tallo de las plantas que presentaron síntomas de marchitez fue cortado a una altura de 5 y $10 \mathrm{~cm}$, respectivamente, a fin de hacer la prueba de exudado bacteriano en agua para confirmar la presencia de marchitez bacteriana.

1 En El Salvador, este término se emplea para designar a un trozo de lazo, cuerda o cordel que suele ser utilizado para amarrar o dar soporte a algo. 
Prueba c. Evaluación del uso de mulch para conocer su efectividad en el control de marchitez bacteriana en condiciones donde los laterales del tomate tocan el suelo

Esta se llevó a cabo a partir del mes de junio hasta el mes de septiembre del 2011, siempre en el mismo jardín privado de la prueba b.

\section{Materiales}

- Plantas de prueba: Plantines variedad Walter, injertados como patrón $y$ variedad BF- OKITSU como injerto

- Materiales para mulch: Rastrojo de arroz y plástico plateado

\section{Tratamientos y replicaciones}

Los tratamientos se muestran en la figura 2, resaltando que se hicieron dos réplicas por cada tratamiento, todas ellas con plantines injertados.

Figura 2. Tratamientos de la prueba c

\begin{tabular}{|c|c|c|}
\hline $\begin{array}{c}\text { Nombre } \\
\text { GN } \\
\text { (Control) }\end{array}$ & Tratamiento & $\begin{array}{c}\text { No. De plantas / } \\
\text { bloque }\end{array}$ \\
GR & $\begin{array}{c}\text { Rastrojo de } \\
\text { arroz }\end{array}$ & 5 plantas \\
GP & $\begin{array}{c}\text { Plástico } \\
\text { plateado }\end{array}$ & 5 plantas \\
\hline
\end{tabular}

Fuente: Elaboración propia
Figura 3. Apariencia de los bloques con plantines ubicados en tres diferentes condiciones

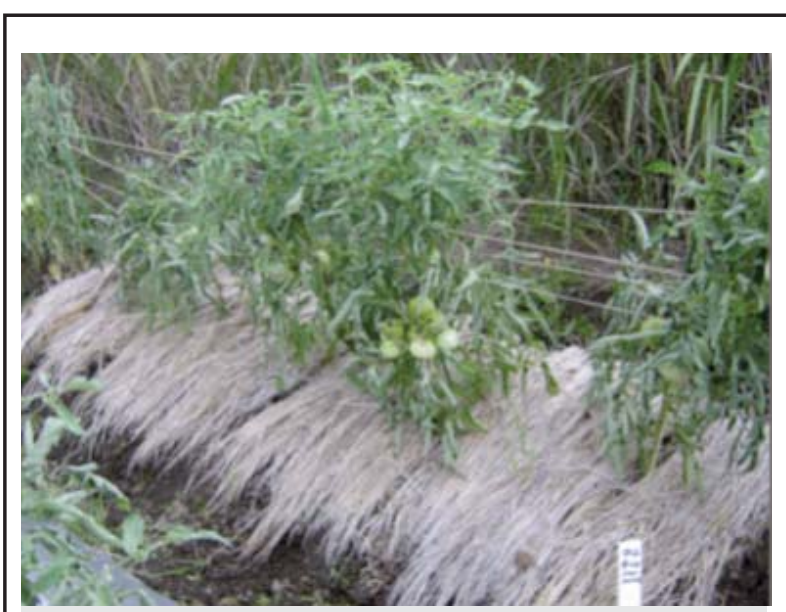

Mulch de rastrojo de arroz

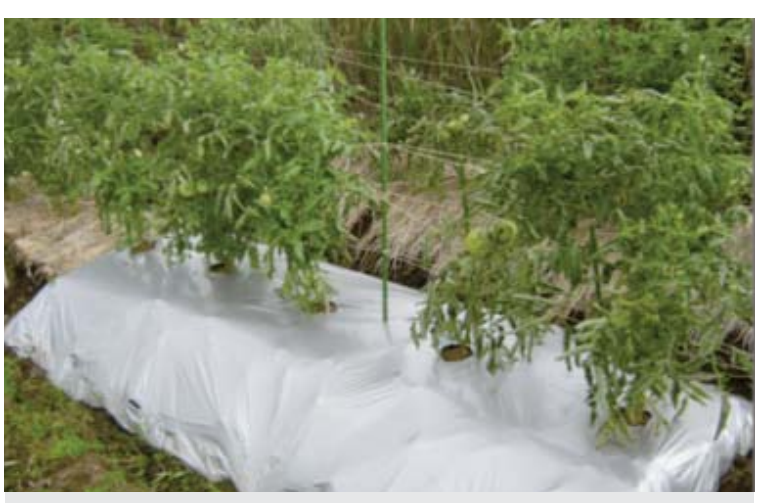

Mulch plástico

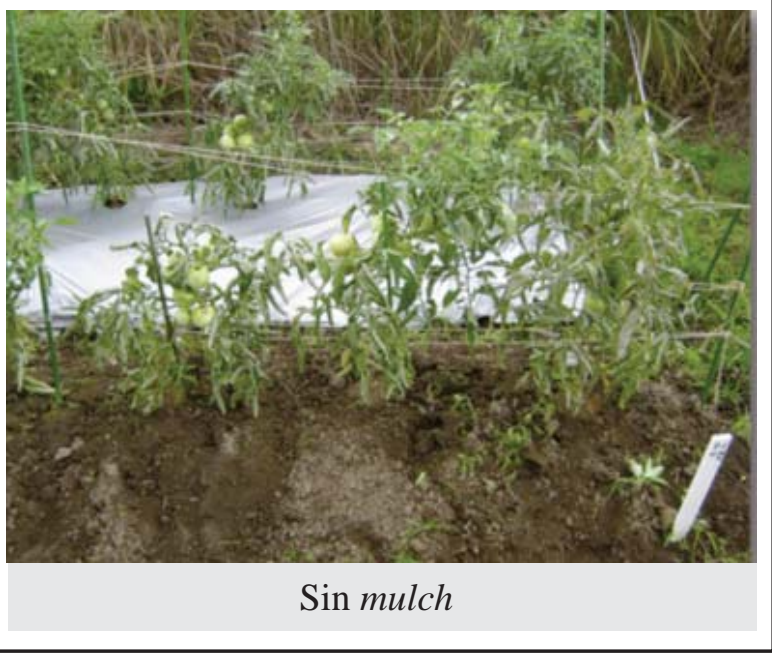

Fuente: Elaboración propia 


\section{Manejo del cultivo y agobio}

El manejo que se realizó fue el mismo que se llevó a cabo en la prueba b. Las ramas laterales y el tallo se agobiaron con el propósito de que tuvieran contacto con el suelo 60 días después del trasplante para evaluar el efecto del mulch (figura 4).

\section{Figura 4. Plantas en condiciones de agobio de laterales y tallos}

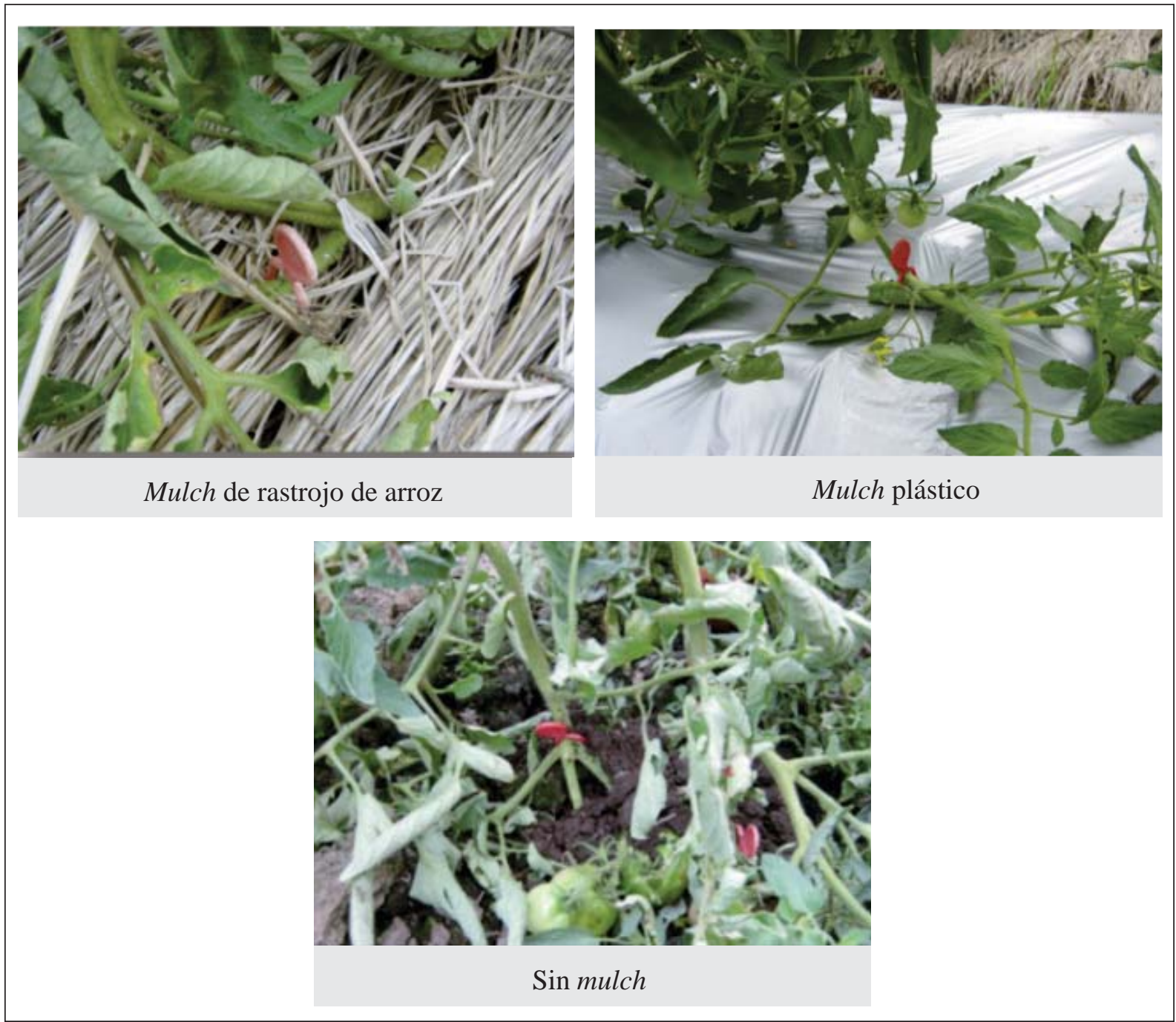

Fuente: Elaboración propia

\section{Resultados y Discusión}

Todas las variedades, incluyendo las variedades que son resistentes a marchitez bacte- rial, según la información de la compañía de semillas, mostraron síntomas de marchitez (figura 6, literal a) cuatro semanas después del trasplante (figura 5). A las plantas que 
mostraron síntomas de marchitez se les cortó el tallo para hacer la prueba de exudado de material bacteriano en agua. Dentro de esta prueba, todas las plantas dieron un dato positivo (figura 6, literal b).
Los resultados obtenidos confirmaron que el suelo utilizado estaba contaminado con la enfermedad de marchitez bacteriana y que la variedad Walter -usada para la prueba b y c- es susceptible a la raza de bacteria en ese campo.

Figura 5. Confirmación de suelo contaminado con plantas de prueba

\begin{tabular}{|c|c|c|c|}
\hline Tipo & Variedad & Tolerante/susceptible & $\begin{array}{c}\text { Días después de trasplante con } \\
\text { síntomas de marchites }\end{array}$ \\
\hline Determinado & Walter & Susceptible & 7 días \\
\hline Indeterminado & Son road & Susceptible & 14 días \\
\hline indeterminado & shunrei & Susceptible & 14 días \\
\hline Indeterminado & Momotaro fight & Susceptible & 22 días \\
\hline
\end{tabular}

Fuente: Elaboración propia

Figura 6. Indicios de marchitez bacteriana

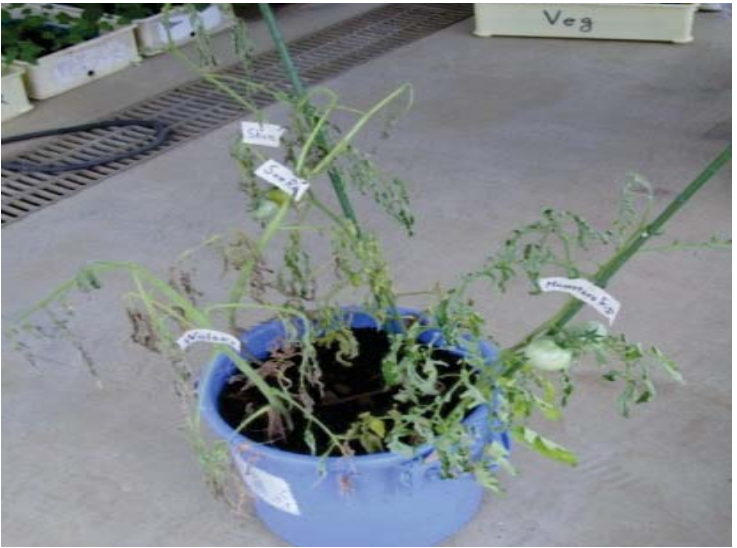

a. Síntoma de marchitez bacteriana

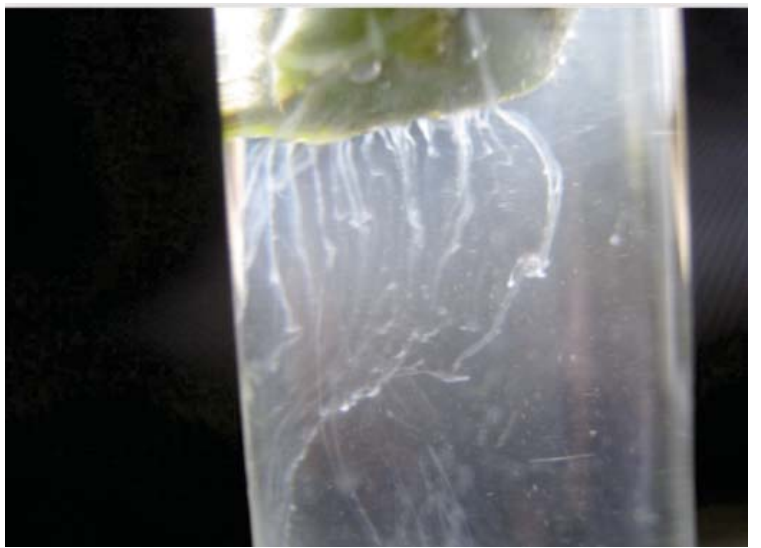

b. Prueba de exudado de material bateriano

Fuente: Elaboración propia 
Durante la evaluación del injerto para controlar la marchitez bacterial, los síntomas de marchitez aparecieron en las plantas no injertadas (figura 7) después de 42 días de ser trasplantadas en el campo contaminado (figura 8). Esta tendencia se fue incrementando gradualmente hasta que finalmente el cien por ciento de las plantas no injertadas presentaron síntomas de marchitamiento. Para confirmar la presencia de bacteria en las plantas con señales de este tipo se hizo la prueba de exudado de material bacteriano en agua.

Sin embargo, todas las plantas que fueron injertadas resistieron el padecimiento y no mostraron síntomas de marchitez en el tiempo que duró el experimentó; e inclusive este comportamiento se mantuvo hasta después de finalizado el estudio.

Figura 7. Planta mostrando marchitez bacterial

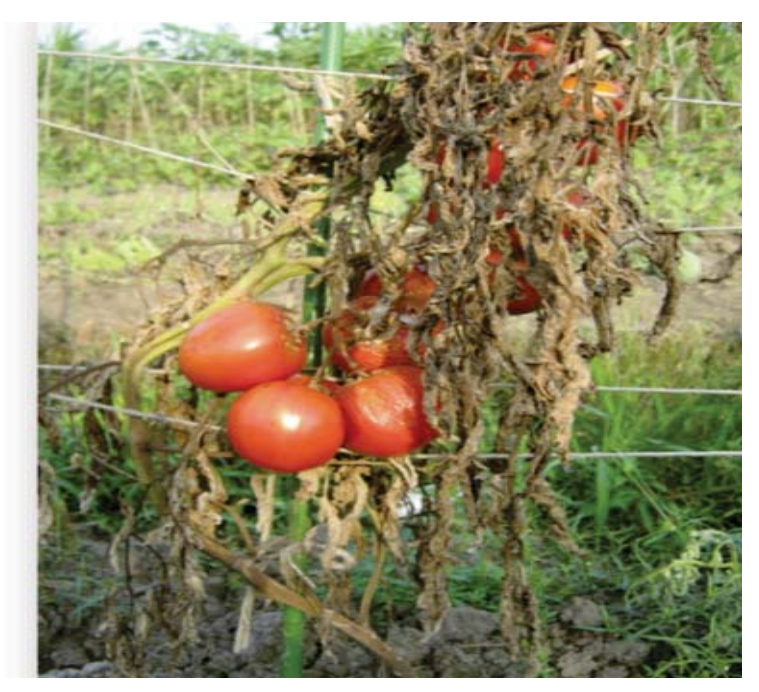

Fuente: Elaboración propia
Figura 8. Porcentaje de supervivencia de plantas en suelo infectado

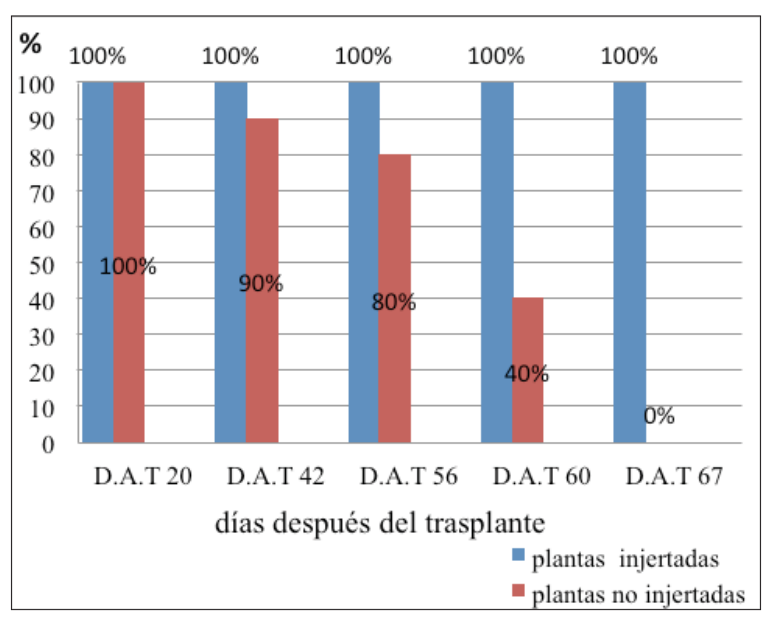

Fuente: Elaboración propia

Posteriormente, para comprobar la prueba c, el experimento se finalizó 75 días después del trasplante. En el tratamiento que no tenía ningún tipo de mulch (figura 9) fue evidente el surgimiento de nuevas raíces. No obstante, ningún bloque mostró síntomas de marchitez.

Figura 9. Desarrollo de raíces de laterales en el bloque sin mulch

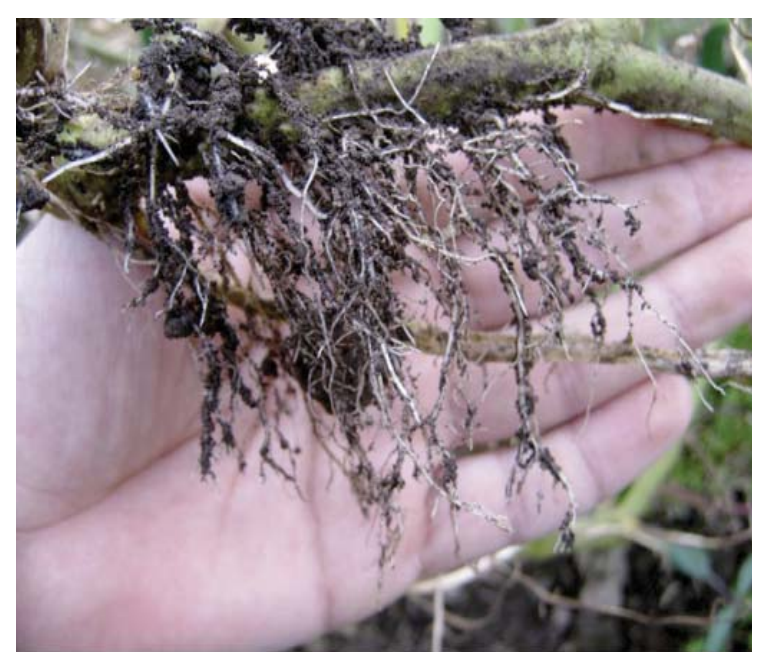

Fuente: Elaboración propia 


\section{Conclusiones}

De acuerdo con la prueba b, el injerto en tomate (Lycopersicon esculentum) de crecimiento determinado puede ser utilizado para controlar marchitez bacteriana. En la prueba $c$, no se observó síntoma de marchitez, inclusive hubo desarrollo de raíces de los laterales. Sin embargo el desarrollo de nuevos brotes de los laterales es poco probable si se hace un buen manejo del cultivo. Por ello se descarta el uso del mulch como material esencial para controlar el marchitamiento por bacteria en plantines de tomate injertados.
El patógeno causante de la enfermedad de marchitez bacteriana, Ralstonia solanacearum, tiene un alto grado de mutabilidad, por lo que existen diferentes razas y biovars, que vuelven su control más difícil. Se concluye que, la selección adecuada del patrón es necesaria cuando se introduce por primera vez el método del injerto en tomate. A pesar de esto, si se encuentra el patrón adecuado, el proceso de injerto puede ser utilizado por los productores salvadoreños de forma exitosa.

\section{Referencias bibliográficas}

AVRDC, The World Vegetable Center, (2001). Integration of antagonistic rhizobacteria and soil solarization for the management of bacterial wilt of tomato caused by Ralstonia solanacearum. AVRDC Report 2001, (54), 110-112. Recuperado de http://avrdclibrary.org/page?pid=70

AVRDC, The World Vegetable Center, (2012). Summer tomato production brings high profits and improves farmers'livelihoods in Bangladesh. Feedback from the field, (14), 1-8. Recuperado de http://avrdc.org/?page_id=1262.

Matsuda, A. (1989). Soil borne disease and its biological control, Second edition Vegetable crops prosuction course. Tsukuba International Center. Japan International Cooperation Agency. Japan.

Mejicano, C. (2010). Report on experiments in Vegetable Cultivation Technology for Small Scale Farmers: V.C. No71

Sherestha, S. (2010). Report on experiments in Vegetable Cultivation Technology for Small Scale Farmers: V.C. No71

Wikipedia. (2013). Ralstonia solanacearum. The free encyclopedia, online. Recuperado de http://en.wikipedia.org/wiki/Ralstonia_solanacearum 